\title{
Peningkatan Kualitas Bentuk Sediaan Produk Minuman Jamu Kunyit Asam Melalui Pembuatan Permen Jelly di Industri Rumah Tangga Jamu Jeng In Desa Wedomartani Ngemplak Sleman Yogyakarta
}

\author{
Wisnu Kundarto*1, Dian Eka Ermawati ${ }^{1}$, Yeni Farida ${ }^{2}$, Indrawati Kurnia Setyani ${ }^{3}$, \\ Vilian Septiana $^{1}$, Nurul Rochmawati ${ }^{1}$ \\ ${ }^{1}$ Program Studi D3 Farmasi, Universitas Sebelas Maret, Surakarta \\ ${ }^{2}$ Program Studi S1 Farmasi, Fakultas MIPA Universitas Sebelas Maret, Surakarta \\ ${ }^{3}$ Jeng In Jamu Homemade, Yogyakarta
}

Kata Kunci: minuman jamu, kunyit asam, permen jelly

\begin{abstract}
Abstrak: Jeng In Jamu Homemade telah rutin memproduksi minuman jamu dalam bentuk segar, dan saat ini sudah mendapatkan izin industri rumah tangga. Industri rumah tangga ini dalam proses mendapatkan sertifikat halal. Jamu kunyit asam segar merupakan produk yang paling banyak diminati konsumen. Kendala yang dihadapi mitra adalah daya tahan produk jamu yang tidak lama sehingga kapasitas produksi selama ini masih terbatas. Pengabdian ini bertujuan untuk memodifikasi jamu kunyit asam segar menjadi bentuk permen jelly sehingga menjadi varian produk yang lebih lama daya simpannya. Tim pengabdian melakukan koordinasi dengan mitra, pendampingan pembuatan permen jelly, evaluasi produk meliputi uji organoleptik dan uji hedonik permen, dan pemberian bantuan alat-alat agar kapasitas produksi meningkat. Hasil uji organoleptik menunjukkan prototype permen jelly kunyit asam yang mempunyai tekstur kenyal, berwarna kuning pucat, berasa khas jamu kunyit asam. Hasil uji hedonik menunjukkan produk permen jelly kunyit asam ini secara umum dapat diterima, tetapi masih perlu perbaikan dalam rasa dan warna agar lebih menarik. Kegiatan follow up masih akan dilakukan sebagai bentuk pendampingan berkelanjutan.
\end{abstract}

\section{Korespondensi: wisnukundarto@staff.uns.ac.id}

\section{PENDAHULUAN}

Minat masyarakat akan obat tradisional seperti jamu masih ada meskipun berbagai jenis suplemen dan vitamin banyak beredar. Jamu menjadi salah satu pilihan masyarakat modern untuk menjaga stamina tubuh. Jumlah konsumsi jamu diperkirakan akan terus meningkat, mengingat masyarakat mulai beralih menggunakan produk alami (Juniman, 2018). Hal ini dimanfaatkan oleh Ibu Indrawati di Desa Wedomartani, Ngemplak, Sleman untuk berwirausaha dengan membuat minuman jamu segar kunyit asam, gula asam, dan beras kencur. Usaha ini sudah dirintis sejak 2013 dan telah mendapatkan sertifikat produksi pangan industri rumah tangga dengan nomor P-IRT 2133404011988-24 dari Dinas Kesehatan Kabupaten Sleman.

Jamu kunyit asam segar merupakan produk yang paling diminati konsumen. Dalam sekali produksi jamu kunyit asam segar sendiri sekitar 40 botol. Produksi ini sampai sekarang masih rutin dilakukan namun belum setiap hari. Hasil produk juga sudah dipasarkan lewat reseller ataupun melalui pameran. Produk jamu Ibu Indrawati diberi logo bertuliskan Jamu Gendong Jeng In. Produk jamu produksi mitra dapat tersaji pada gambar 1. 


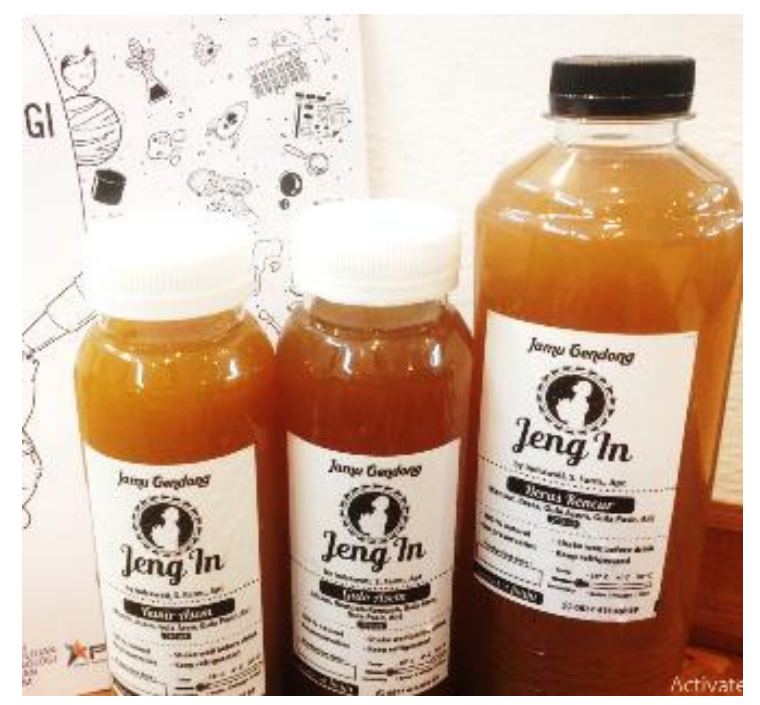

Gambar 1. Contoh produk minuman jamu segar buatan mitra (dokumentasi pribadi)

Hasil identifikasi masalah mitra ada dua. Pertama, produksi masih berupa sediaan jamu segar sehingga daya tahan (self life) produk hanya berkisar antara 12-24 jam pada suhu kamar dan 3 hari apabila disimpan dalam lemari es. Produksi belum dilakukan setiap hari karena masih berupa sediaan jamu segar yang dikemas dengan botol dan tidak bisa bertahan lama. Kedua, proses produksi masih menggunakan peralatan terbatas sebagai contoh masih menggunakan satu kompor dalam proses pemasakan, dan satu blender dalam proses penghalusan bahan. Hal ini tentu kurang praktis karena proses pembuatan jamu harus dilakukan beberapa kali untuk memenuhi target produksi. Dari hasil wawancara dengan mitra juga didapatkan informasi bahwa mitra pernah mendapatkan pengabdian terkait pembuatan jamu instan sebagai bentuk diversifikasi produk dari Lembaga Ilmu Pengetahuan Indonesia. Meskipun demikian, animo masyarakat terhadap jamu kunyit asam dalam bentuk cair masih tinggi sehingga produksi jamu kunyit asam instan juga masih belum rutin. Oleh sebab itu perlu dilakukan transfer pengetahuan dan teknologi untuk membuat bentuk sediaan jamu berkualitas yang lebih bertahan lama sehingga produksi dapat dilakukan tiap hari.

Pengabdian ini bertujuan menawarkan modifikasi bentuk sediaan jamu kunyit asam segar menjadi bentuk permen jelly sebagai alternatif diversifikasi produk. Permen jelly menurut Badan Standarisasi Nasional (2008) didefinisikan sebagai kembang gula bertekstur lunak yang diproses dengan penambahan komponen hidrokoloid seperti agar, gum, pektin, pati, karagenan, gelatin, dan lain-lain yang digunakan untuk modifikasi tekstur sehingga menghasilkan produk yang kenyal. Diharapkan dari hasil pengabdian ini, prototype produk permen jelly dapat menjadi alternatif baru produk jamu mitra yang disukai konsumen dan lebih tahan lama daripada jamu bentuk segar.

\section{METODE KEGIATAN}

Metode pelaksanaan PKM dalam rangka pemberdayaan masyarakat dalam bentuk modifikasi jamu kunyit asam akan direalisasikan dengan mekanisme yaitu (1) sosialisasi program kegiatan, (2) pendampingan cara produksi permen jelly kunyit asam, (3) uji organoleptis dan uji kesukaan prototype produk, dan (5) evaluasi hasil dan follow up. Dalam proses sosialisasi, tim pengabdian memberikan sosialisasi mengenai tujuan, rencana, waktu 
pelaksanaan, serta rencana sistematis kegiatan. Dalam proses pendampingan cara produksi permen jelly, tim pengabdian memberikan transfer pengetahuan dan teknologi pembuatan permen jelly melalui demo proses produksi. Mitra juga melakukan praktek pembuatan secara langsung. Mitra didampingi oleh tim pengabdian selama proses pelatihan. Uji organoleptis dan uji kesukaan terhadap prototype produk permen jelly dilakukan dengan menyebarkan kuesioner. Uji organoleptik dilakukan dengan pengamatan secara visual menggunakan panca indera untuk mendiskripsikan tekstur, warna, aroma, dan penampilan produk. Hasil uji organoleptik dan uji kesukaan disajikan secara deskriptif untuk memberikan gambaran. Evaluasi dilakukan sebagai kegiatan akhir meliputi evaluasi peningkatan keterampilan mitra dan evaluasi dampak kegiatan.nKegiatan follow up akan dilakukan sebagai bentuk pendampingan berkelanjutan. Permasalahan yang dihadapi setelah kegiatan pengabdian akan dikaji secara bersama-sama melalui evaluasi kegiatan dan umpan balik dari mitra.

\section{HASIL DAN PEMBAHASAN}

Pengabdian masyarakat yang dilakukan telah melalui tahap-tahap yang sudah direncanakan. Tim pengabdian telah melaksanakan sosialisasi kegiatan, pelatihan pembuatan permen jelly, uji organoleptik dan uji kesukaaan, serta pemberian bantuan alat-alat untuk peningkatan kapasitas produksi seperti terlihat pada gambar 2 .

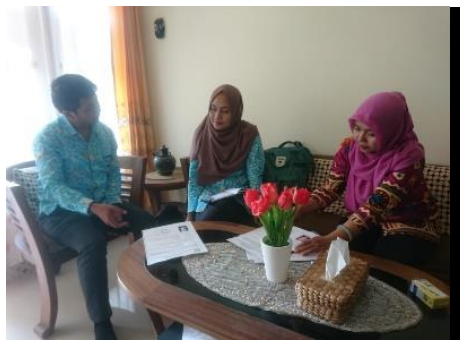

(a)

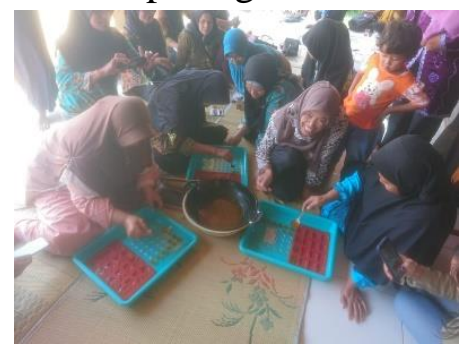

(b)

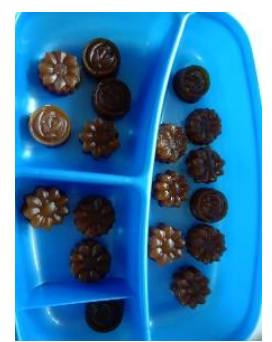

(c)

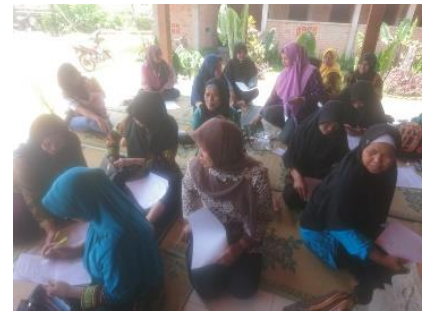

(d)

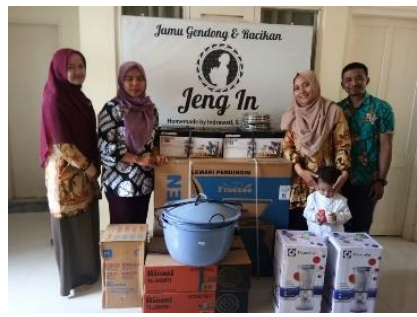

(e)

Gambar 2. Rangkaian kegiatan pengabdian; (a) sosialisasi kegiatan (b) pelatihan pembuatan permen jelly (c) prototype permen jelly (d) uji organoleptik dan uji kesukaan permen (e) serah terima alat-alat ke mitra (dokumentasi pribadi)

Formula permen jelly mengacu penelitian Aryani dkk (2015) dan Arianto (2016) dengan modifikasi. Uji organoleptik dan uji kesukaan permen jelly menggunakan kuesioner dan dibagikan ke 25 responden. Sebanyak 9 responden dinyatakan tidak valid karena ada jawaban ganda, isian kuesioner tidak lengkap, dan tidak ada tanda tangan responden. Adapun hasil kuesioner dapat dilihat pada tabel 1. 
Tabel 1. Hasil uji organoleptik dan uji kesukaan prototype permen jelly

\begin{tabular}{lccc}
\hline \multirow{2}{*}{ Hal yang dinilai } & \multicolumn{3}{c}{ Tingkat Kesukaan $(\mathbf{n = 1 6})$} \\
\cline { 2 - 4 } & Tidak Suka & Netral & Suka \\
\hline Aroma & 1 & 5 & 10 \\
Rasa & 1 & 2 & 13 \\
Warna & 0 & 4 & 12 \\
Tekstur & 1 & 8 & 7 \\
Penampilan produk & 0 & 6 & 10 \\
\hline
\end{tabular}

Hasil evaluasi tabel 1 menunjukkan bahwa secara umum konsumen menyukai prototype produk permen jelly. Meskipun demikian masih perlu penyempurnaan formula dalam hal rasa, aroma, dan tekstur. Prototype permen jelly ini masih berasa kunyit asam sehingga perlu tambahan pemanis jika menginginkan rasa manis. Pengamatan organoleptis juga menunjukkan dalam suhu lemari es, prototype produk ini juga hanya bertahan selama 3 hari, dan akan meleleh pada suhu kamar. Perbaikan formula, kegiatan monitoring, dan follow up masih akan dilakukan tim sebagai bentuk pendampingan berkelanjutan.

Evaluasi dampak kegiatan pengabdian adalah peningkatan kapasitas produksi jamu segar. Adanya bantuan alat-alat terutama kompor, panci, dan blender dapat membantu proses pembuatan jamu segar menjadi lebih efisien. Adanya freezer dan cooling box dapat digunakan untuk menambah kapasitas penyimpanan di tempat mitra maupun pada saat mitra mengikuti kegiatan pameran. Mitra secara mandiri telah bekerjasama dengan pihak ketiga dalam hal penjualan online. Terkait hal tersebut tim hanya membantu mitra dalam pemasangan neonbox sebagai sarana promosi. Diharapkan hal ini akan memudahkan akses menuju lokasi mitra jika ada pemesanan secara online. Prototype produk yang masih terus dikembangkan akan juga dimasukkan ke dalam daftar produk.

\section{KESIMPULAN DAN SARAN}

Kesimpulan yang diperoleh dari pengabdian ini adalah mitra telah mendapatkan transfer pengetahuan dan teknologi dalam pembuatan prototype permen jelly kunyit asam. Mitra juga telah mendapatkan bantuan alat-alat untuk meningkatkan kapasitas produksi. Meskipun demikian, formula prototype permen jelly ini ternyata masih belum sempurna, terutama dalam hal rasa, aroma, dan tekstur. Tim masih akan terus melakukan monitoring dan follow up dalam hal pengembangan formula supaya dapat diterima konsumen lebih baik lagi. Saran-saran yang dapat diberikan adalah perlu juga untuk mendesain kemasan produk serta pengajuan izin POM TR sebagai added value produk.

\section{UCAPAN TERIMA KASIH}

Penulis mengucapkan terima kasih kepada Universitas Sebelas Maret yang telah memberikan bantuan finansial melalui skema PNBP UNS Tahun Anggaran 2019. 


\section{DAFTAR PUSTAKA}

Arianto, D., 2016, Variasi Jenis dan Konsentrasi Gelling Agent Terhadap Karakteristik Marshmallow Buah Naga (Hylocereus undatus \& Hylocereus polyrizus), Skripsi, Program Studi Teknologi Pangan Fakultas Teknik Universitas Pasundan, Bandung.

Aryani, D., Saifullah, T.N., dan Murti, Y.B., 2015, Pembuatan Chewable Lozenges Ekstrak Daun Legundi (Vitex trifolia L.) Dengan Variasi Proporsi Basis Gliserin-Gelatin., Trad Med J., Vol 20 (2) : 98-104.

Badan Standarisasi Nasional (2008), SNI 3547.2.2008 Kembang Gula-Bagian 2: Lunak, Badan Standarisasi Nasional, Jakarta.

Juniman, P.T., 2018, Jamu dan Obat Herbal Masih Diminati Masyarakat, tersedia di https://www.cnnindonesia.com/gaya-hidup/20180417184633-255-291506/jamu-dan-obatherbal-masih-diminati-masyarakat, diakses 31 Januari 2019. 